\title{
Research
}

\section{The Use of Traditional Ecological Knowledge in Forest Management: an Example from India}

\author{
$\underline{\text { Lucy Rist }}^{1}, \underline{\text { R. Uma Shaanker }}^{2,3}, \underline{\text { E. J. Milner-Gulland }}^{4}$, and Jaboury Ghazoul ${ }^{1}$
}

\begin{abstract}
Many forest communities possess considerable knowledge of the natural resources they use. Such knowledge can potentially inform scientific approaches to management, either as a source of baseline data to fill information gaps that cannot otherwise be addressed or to provide alternative management approaches from which scientists and managers might learn. In general, however, little attention has been given to the relevance of quantitative forms of such knowledge for resource management. Much discussion has focused on the integration of traditional ecological knowledge (TEK) into management, but less attention has been paid to identifying specific areas where it is most useful and where it may be most problematic. We contrasted scientific data with information from TEK in the context of a threat to the sustainable harvesting of a nontimber forest product (NTFP) of livelihood importance in southern India, specifically, a fruit tree infected by mistletoe. The efficiency of deriving information from NTFP harvesters compared to scientific field studies was assessed. We further evaluated the potential of TEK to provide novel solutions to the management problem in question, the degree to which TEK could provide quantitative information, and the biases that might be associated with information derived from TEK. TEK complemented previously gathered ecological data by providing concordant and additional information, but also contradicted some results obtained using a scientific approach. TEK also gave a longer-term perspective with regard to NTFP harvesting patterns. Combining information on historical and current harvesting trends for the NTFP with official data suggests that current assessments of sustainability may be inaccurate and that the use of diverse information sources may provide an effective approach to assessing the status of harvested resources.
\end{abstract}

Key Words: amla; forest management; nontimber forest product; participatory management; Phyllanthus emblica; Phyllanthus indofischeri; Taxillus tomentosus; traditional ecological knowledge

\section{INTRODUCTION}

Traditional, indigenous, and local ecological knowledge (TEK, IEK, and LEK, respectively) have all been used to refer to sources of knowledge about species, ecosystems, or practices held by people whose lives are closely linked to their natural environment (Freeman 1992, Gadgil et al. 1993, Berkes 1999). The distinction between traditional/ indigenous and local knowledge is of greatest significance because the first two terms imply the development of knowledge over a longer timescale (Gilchrist et al. 2005). However, some communities with a more recent association with an area or resource still possess a detailed acquired knowledge or understanding of the ecology and management of that area and the resources they use. Communities that are dependent on natural resources can rapidly develop insight into factors influencing resource availability or quality. Such information can be shared among users and can develop into a substantial body of knowledge (e.g., Acheson et al. 1998, Hanna 1998). Thus, knowledge recently acquired by local communities can be as important as "traditional" information generated over a longer timescale (Mallory et al. 2003). Although we recognize the value of more recently developed bodies of knowledge, we use the term TEK because it has predominant usage among conservationists and resource managers and is not restricted in application to indigenous peoples alone. 
The use of TEK has found favour in conservation planning and resource assessment for three reasons: efficiency, additionality, and community engagement (Berkes et al. 2000, Pierotti and Wildcat 2000, Sheil and Lawrence 2004, Drew 2005). When TEK corresponds well to scientific data, it can be a more efficient method of acquiring information. Although such bodies of knowledge develop over significant periods of time and represent considerable investment by knowledge holders in experimentation and observation, rigorous social science methods can often gather some of this information in less time and at less cost than formal ecological research. Resource users often interact with a landscape at a much larger scale and over longer periods of time than are possible in standard scientific investigations (Hobbs 2003, Fraser et al. 2006, Wehi 2009). In addition, programs that garner the support of local people through their participation have a greater chance of acceptability and therefore long-term sustainability (Schwartzman et al. 2000, Bowen-Jones and Entwistle 2002, Danielsen et al. 2005).

TEK can not only add to an existing body of scientific knowledge, but can present a completely different picture of reality, especially when held within a different cosmological and ethical framework. When knowledge about the consequences of management is scarse, these alternative narratives can be of great value. The practical application of TEK is growing. Many studies have used such knowledge effectively to address conservation aims (Colding 1998, Johannes 1998, Fraser et al. 2006), sustainable resource use (Berkes 1999, Castello et al. 2009), and climate change (Couzin 2007).

The demonstrated complementarity between traditional and scientific sources of information has validated the use of TEK in ecological research, including in harvesting assessment (Berkes 1999, Castello et al 2009). However, there remains little discussion of cases in which TEK and scientific studies appear contradictory, and few studies have focused on identifying specific strengths and inadequacies, including the use of more quantitative information. Therefore, we studied the validity and additionality of TEK in terms of quantitative, as well as qualitative, management-relevant data in the context of a specific management problem: the infection of a valuable nontimber forest product (NTFP) by a native but invasive mistletoe.
The study was conducted in a wildlife sanctuary in southern India, where an NTFP of significant livelihood importance is currently threatened because of intense infestation by a native mistletoe (Taxillus tomentosus; Rist et al. 2008b). The fruit of amla (Phyllanthus emblica L. and Phyllanthus indofischeri Bennet), contributes $>10 \%$ of the cash income of the local population, yet mistletoe infection is currently reducing fruit production and leading to significant tree mortality, with implications for livelihood and ecology (Hegde et al. 1996, Rist et al. 2008b). Data from field studies carried out over two years were compared with TEK gathered through interviews with harvesters. By assessing the correspondence between the two information sources, including validity and additionality, areas where TEK may be most useful in resource assessment were identified. Current and historical harvesting trends as perceived by resource users were investigated and compared with official harvest records to understand more fully the impact of mistletoe infection. This included investigating explanations for a discrepancy between sustainability as indicated by harvesting records and by local perspectives on resource status.

\section{METHODS}

\section{Study location}

The Biligiri Rangaswamy Temple (BRT) Wildlife Sanctuary $\left(11.40^{\circ}-12.098^{\circ} \mathrm{N}\right.$ and $77.05^{\circ}-77.158^{\circ}$ $\mathrm{E})$ is located in the state of Karnataka, India, on the easternmost ridge of the Western Ghats (Fig. 1). The $540-\mathrm{km}^{2}$ protected area faces multiple threats, including fire, encroachment from villages on the borders of the sanctuary, and the spread of invasive species. The area is home to the indigenous Soliga community, as well as a smaller nonindigenous population. Traditionally semi-nomadic, the Soligas were settled into villages and allotted land for agriculture when the area was declared a wildlife sanctuary in 1976. In addition to wage labour and agriculture, these communities supplement their livelihoods through the collection of a wide variety of NTFPs, including fruits, honey, and lichens. Soliga dependence on NTFPs for household income is extensive, ranging from approximately $30 \%$ in the forest margin to $>60 \%$ in interior villages (Hegde et al. 1996, Uma Shaanker et al. 2002). 
Fig. 1. The Biligiri Rangaswamy Temple (BRT) Wildlife Sanctuary in Karnataka, India. Map provided by ATREE.

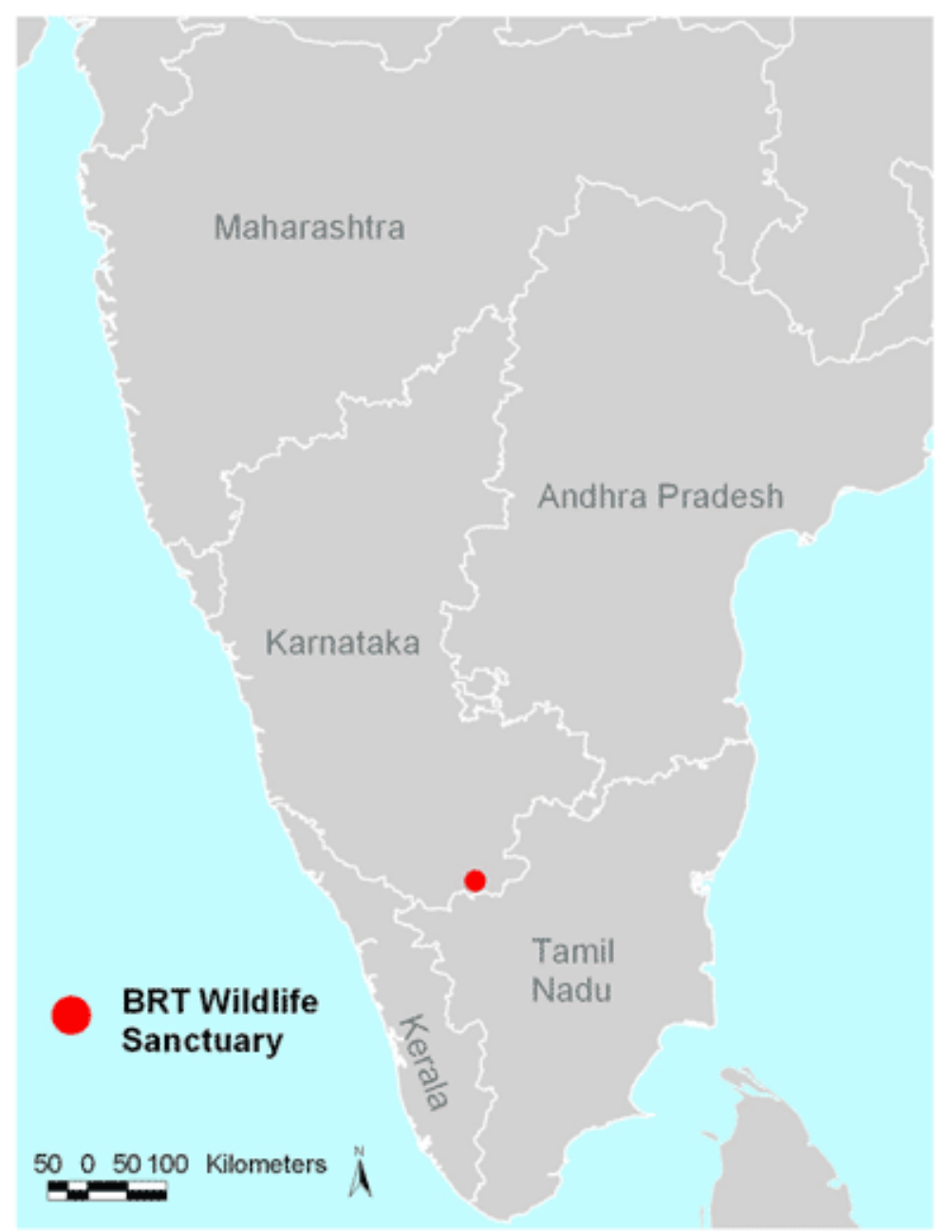

\section{Interviews with harvesters}

Between February and August 2006, 47 amla harvesters from the BRT sanctuary were interviewed (Table 1). Respondents were selected from 16 villages across the sanctuary, out of a total of 57. By including individuals knowledgeable about all portions of the geographic area relevant to the resource, the data represent a good picture of Soliga knowledge about amla in BRT. Two to five respondents were interviewed from each village. Interviewees were selected based on their identification as established amla harvesters by one or more peers. Harvesters can be confidently identified as those possessing traditional knowledge because at this site, only the indigenous communities have NTFP harvesting rights. Other Soligas who do not participate in the amla harvest, or indeed non-Soligas, may also hold knowledge on this subject, but experienced harvesters can be expected to possess the greatest knowledge (Davis and Wagner 2003). All respondents were interviewed in the local language by a local research assistant who was trained to conduct the surveys.

The questionnaire consisted of a mix of 50 specific and open-ended questions, with the opportunity for the interviewees to elaborate on questions as they saw fit (Laird 2002, Martin 2004). If they could not answer a question, interviewees typically indicated 
Table 1. Characteristics of the interviewed harvesters. ${ }^{\dagger}$

\begin{tabular}{ll}
\hline \hline Characteristic & Value \\
\hline Number of villages & 16 \\
Number of harvesters & 47 \\
Gender & Male $87 \%$, female $13 \%$ \\
Age & $32-80 \mathrm{yr}($ mean $=50 \pm 13.1 \mathrm{yr})$ \\
Harvesting experience & $10-30 \mathrm{yr}($ mean $=22 \pm 5.1 \mathrm{yr})$ \\
Main occupation & Agriculture $66 \%$, NTFP collection $15 \%$, daily wage labour $17 \%$, housewife \\
& $2 \%$ \\
Secondary occupation & NTFP collection $45 \%$, no secondary occupation $43 \%$, daily wage labour $9 \%$, \\
& agriculture $4 \%$
\end{tabular}

†The collection of many nontimber forest products (NTFPs), including amla, is often a seasonal activity, as reflected in the dominant reporting of agriculture as a primary occupation. Amla harvesters vary in the extent to which they participate in the harvesting of other NTFPs; for some, amla is the only NTFP gathered commercially.

Nontimber forest product.

that they did not know. Questions were in two categories: the first focused on natural history observations, and the second was specific to management. Questions in the natural history category targeted information on host tree associations, mistletoe distribution, optimal growing conditions, phenology, pollination, and dispersal. Questions associated with management pertained to more specific information on the effects of mistletoe infection on the growth, productivity, and mortality of amla; the variation in susceptibility between the two amla species; and the comparative productivity levels of infected and uninfected trees. The answers to each question were compared with available ecological data derived from field studies (Rist et al. 2008b, Rist 2009). We use the term "accurate" only in reference to whether the answer matched the available ecological data.

We investigated perceived changes in the density of amla trees both surrounding the villages and in the forest as a whole. Harvesters are familiar with such distinctions through their involvement in participatory NTFP assessments conducted by a local nongovernmental organization (Setty et al. 2008). Information on current and past (15 years previous) harvesting activities was collected: average yield of amla per day, number of harvest days, and standard rate earned per unit collected. The perceived total amount collected per season for each harvester was calculated based on the number of days spent harvesting multiplied by the individual daily collection amount. We validated the assumption that harvesters accurately perceive harvest quantities by comparing their responses with official records of amla prices. When assessing current and historical harvesting patterns, we also questioned harvesters with respect to price trends between 1990 and 2005. Their responses were compared with official prices records over this time period. With no reason to suspect that their collection quantities were any more open to errors in memory or to other sources of bias than price data, this comparison provided evidence of reliable recall of historical harvest levels (Saenz-Arroyo et al. 2005). 
Harvesters may react in various ways to the perceived opportunities and threats of being researched, for example, seeking to bias their recorded forest uses upward so as to be better recognized, or downward to hide illegal activities or due to suspicion about the intended use of the information given (Sheil and Wunder 2002). In BRT, the cutting of tree branches or the setting of fire is prohibited by the Forest Department, and the harvesting of amla fruits is also periodically banned. The interviewer was a resident of BRT and so was well known and trusted by local Soliga harvesters. Evidence of this trust is provided by the fact that harvesters were open about their amla management practices, even to the extent that they reported being engaged in activities that they knew to be prohibited by the Forest Department. Harvesters were therefore considered to be describing their knowledge accurately to the best of their abilities and to be reporting management practices honestly.

\section{Scientific knowledge and formal harvest records}

Our investigation was conducted in parallel with ecological studies that assessed mistletoe distribution patterns and alternative management approaches (Rist et al. unpublished manuscript). Experimental studies, including the removal of mistletoes by hand, tested the success of local and official methods of controlling mistletoe infection (Rist et al. 2008b). Additional published studies (e. g., Sinha and Bawa 2002, Ganesan and Setty 2004, Sinha and Brault 2005) also provided data with which TEK could be compared. Amla harvest records over a 15-year period (1990-2005) were obtained from a cooperative marketing society involved in NTFP collection in BRT. Results of current and historical harvesting patterns from TEK interviews were compared with trends in these records and with official unit prices over this period.

\section{RESULTS}

\section{Ecological knowledge of amla harvesters}

All respondents were familiar with the mistletoe referred to locally as bili uppilu or antu uppilu. In fact, many respondents identified five or more mistletoe species present in BRT, and their descriptions matched results of mistletoe diversity surveys (L. Rist unpublished data). Both TEK and scientific approaches identified $P$. emblica and $P$. indofischeri as the main hosts. Although all considered infection to be greater in P. emblica, when explaining landscape level patterns of infection, all harvesters chose to describe forest areas with specific microclimates e.g., hill tops or dense moist forest, rather than distinguishing on the basis of scrub and deciduous forest classifications, as in scientific studies (Table 2). Such local classifications may be more useful when locating priority areas for the implementation of management. All interviewees cited taller, older trees as bearing a greater number of mistletoes. When asked about the distribution of mistletoe infections on an individual tree, all but two interviewees stated that mistletoes are found on thin outer branches. Three harvesters added that mistletoes were only found on the trunk in very heavily infected trees. Despite subsequently emphasizing the preference of dispersing birds for these thin branches, none of the harvesters linked their observations to this documented preference in dispersal behavior (Aukema and Martínez del Rio 2002).

TEK provided information more efficiently (in terms of data collection effort expended by scientists) and of equivalent or higher accuracy than conventional ecological studies. For example, TEK closely matched field data on mistletoe phenology. Phenological studies took place over 12 months, requiring two field workers and approximately 24 $\mathrm{h} /$ month of fieldwork, for a total of $288 \mathrm{~h}$ for the entire study. Social science methods for gathering harvester information took considerably less time and resources; 47 interviews were conducted by one individual, for a total of approximately $70.5 \mathrm{~h}(1.5$ $\mathrm{h} /$ interview). Where efficiency is considered a matter of not duplicating effort expended in generating knowledge necessary for management, rather than just time spent in the field by scientists, the use of TEK becomes even more valuable.

Opinion varied as to how the effects of infection differed according to tree age and species (i.e., $P$. emblica or $P$. indofischeri); $58 \%$ considered $P$. indofischeri to suffer more significantly when infected, $11 \%$ considered P. emblica to suffer more, and $30 \%$ considered that there was no difference between the two species. Also, $49 \%$ and $44 \%$ of harvesters considered younger and older trees, respectively, to be more severely affected by infection by mistletoes, and $1 \%$ considered there to be no difference. A scientific investigation of the 
Table 2. Summary of harvester and scientific knowledge about mistletoe ecology and distribution and the effects of mistletoe infection on amla.

\begin{tabular}{|c|c|c|c|c|}
\hline Characteristic & $\mathrm{TEK} \dagger$ & Data type & Ecological studies & Concordance \\
\hline Primary host & P. emblica, $P$. indofischeri & Qualitative & $\begin{array}{l}82 \% \text { of mistletoes sampled observed } \\
\text { on } P . \text { emblica and } P \text {. indofischeri (Rist } \\
\text { et al. } 2008 b \text { ) }\end{array}$ & Excellent \\
\hline Secondary host & 35 species & Quantitative & 12 species (Rist et al. $2008 b$ ) & Some \\
\hline Infection prevalence & $\begin{array}{l}0.5-0.8(\text { mean }=0.57 \\
\pm 0.11) \ddagger\end{array}$ & Quantitative & 0.51 (Rist et al. 2008b) & Excellent \\
\hline $\begin{array}{l}\text { P. emblica vs. } P \text {. } \\
\text { indofischeri infection }\end{array}$ & $\begin{array}{l}\text { P. emblica is more } \\
\text { commonly infected; older, } \\
\text { taller trees are more often } \\
\text { infected and have more } \\
\text { mistletoes }\end{array}$ & Qualitative & $\begin{array}{l}\text { Prevalence } 0.64 \text { in } P \text {. emblica and } \\
0.38 \text { in } P \text {. indofischeri (Rist et al. } \\
2008 b \text { ); greater probability and } \\
\text { intensity of infection in taller trees } \\
\text { (Rist et al. } 2008 b \text { ) }\end{array}$ & Excellent \\
\hline Forest type & $\begin{array}{l}\text { Deciduous forest, i.e., moist, } \\
\text { dense forest and hill tops }\end{array}$ & Qualitative & Deciduous forest (Rist et al. 2008b) & Excellent \\
\hline Phenology & $\begin{array}{l}\text { Flowers during summer; } \\
\text { fruits at end of summer prior } \\
\text { to rains }\end{array}$ & Qualitative & $\begin{array}{l}\text { Peak flowering: April-July (summer); } \\
\text { peak fruiting: August-November } \\
\text { (rains in July/August; Rist 2008) }\end{array}$ & Excellent \\
\hline Flower visitors & $\begin{array}{l}\text { Flowerpeckers, sunbirds, } \\
\text { insects }\end{array}$ & Qualitative & $\begin{array}{l}\text { Flowerpeckers (Davidar 1983); } \\
\text { lorikeet, drongo (Shrestha 2000) }\end{array}$ & Some \\
\hline Dispersal & $\begin{array}{l}\text { Birds, squirrels, bats, rats, } \\
\text { monkeys, and wind }\end{array}$ & Qualitative & $\begin{array}{l}\text { Flowerpeckers (Davidar 1978), } \\
\text { bulbuls (Ali and Ripley 1983, } \\
\text { Shrestha 2000) }\end{array}$ & Poor \\
\hline $\begin{array}{l}\text { Favorable conditions for } \\
\text { mistletoe growth }\end{array}$ & Moist, dense forest & Qualitative & $\begin{array}{l}\text { High moisture (Reid and Lange 1988), } \\
\text { high light levels (Norton and Reid } \\
\text { 1997) }\end{array}$ & Good \\
\hline Effects on growth & Reduces growth & Qualitative & $\begin{array}{l}\text { Significantly reduces growth (Setty } \\
\text { 2004) }\end{array}$ & Good \\
\hline Effects on productivity & $\begin{array}{l}25-100 \% \text { reduction in fruit } \\
\text { production }(\text { mean }=68 \\
\pm 20.7 \%) \S\end{array}$ & Quantitative & $\sim 44 \%$ decrease (Setty 2004)§ & Good \\
\hline Effects on survival & $\begin{array}{l}\text { All infected trees die; } \\
\text { mortality occurs } 2-10 \mathrm{yr} \\
\text { following infection }\end{array}$ & Quantitative & $\begin{array}{l}54 \% \text { mortality rate of infected trees } \\
\text { over } 4 \text { yr (Setty 2004) }\end{array}$ & Good \\
\hline $\begin{array}{l}\text { Differential } \\
\text { susceptibility }\end{array}$ & $\begin{array}{l}P . \text { indofischeri more } \\
\text { susceptible than } P \text {. emblica }\end{array}$ & Qualitative & $\begin{array}{l}\text { Effect on growth only in } P \text { emblica; } \\
\text { effect on productivity is greater in } P \text {. } \\
\text { emblica (Sinha and Bawa 2000) }\end{array}$ & Poor \\
\hline
\end{tabular}

$\dagger$ Traditional ecological knowledge.

\$ Harvester estimates of the proportion of the amla population infected by mistletoes and the decline in production of the average infected tree.

$\S$ Calculated from mean fruit production figures in Setty (2004) for infected and uninfected trees $(P$. emblica only). No information was given on the infection levels in these trees. 
effects of infection on growth and productivity using a before-and-after design found that infection reduced growth and fruit production to a greater degree in $P$. emblica than in $P$. indofischeri (Sinha and Bawa 2002).

Regarding quantitative measures, harvester and scientific assessments of infection prevalence in the amla population were closely matched, with no significant difference between the two estimates ( $t$ $=2.16$, $\mathrm{df}=48.1$, nonsignificant; Table 2). In contrast, estimates of the magnitude of effects on productivity differed considerably; a standard scientific approach showed a $44 \%$ decline in fruit production (Setty 2004) whereas a mean value from TEK indicated a $68 \%$ decline. Mortality rates were not directly comparable. In a scientific study, infected trees were monitored over a period of four years; 54\% died during this time (Setty 2004). Harvesters gave estimates of time to death following initial infection of between 2 and 10 years; all said that there is no recovery from infection and that all infected trees eventually die.

Harvesters identified over twice as many tree species as hosts than found in forest surveys (Table 2 ). There are two possible explanations for this difference; either some host-mistletoe associations are so infrequent that the scientific survey failed to detect these species as hosts, or harvesters falsely identified these species as hosts. In considering the distribution of citations over the 19 additional species identified, two of these, Kydia calycina and Mallotus philippensis, were cited by $>40 \%$ of harvesters, indicating that a large number of them would have had to falsely identify these species for the second explanation to be valid. Rare host associations are likely to be particularly difficult to detect when the relative abundance of the host species itself is low. Using the relative abundance of these two species and a global per-tree measure of the probability of infection, the possibility that forest surveys could have missed an incidence of infection for these species was considered. The global measure was calculated by averaging the number of infected trees across all sampled species, assuming equal probability of infection across species. Based on species abundance, less than one infected tree was expected in the ecological surveys for both Kydia calycina and Mallotus philippensis (Appendix 1). We also looked at Grewia tilifolia, a species that was citied at a similar high frequency by harvesters and that had been recorded as a host three times in the survey. Using the same global measure of probability of infection, four to five infected trees were expected to have been observed in the survey, suggesting that these values were reliable. Two species were not cited as hosts by harvesters, but were found to be hosts in the survey: Stereospermum personatum and Wendlandia thyrsoidea. These together accounted for only $0.004 \%$ of all observed mistletoe infections (Fig. 2).

Harvesters were asked to list the species that they had observed eating mistletoe fruits, and were also asked about the mechanisms by which mistletoes spread. Although the two questions were aimed at establishing the same information, i.e., identifying mistletoe dispersal agents, the responses differed widely both from each other and from the scientific information. Bats were cited as fruit predators, but not as dispersers. Wind was cited as a dispersal mode for mistletoes by $20 \%$ of harvesters, one of who considered this to be the primary dispersal mechanism (Table 2). With eight additional bird species, harvesters identified a much higher diversity of bird dispersers than currently recognized in published research (Table 2).

Harvesters had detailed knowledge of the infection process and the mechanisms behind mistletoe spread. Two harvesters identified growth of epicortical roots as a mechanism of infection accumulation within infected trees and considered this in their assessment of suitable management strategies. Epicortical roots are adventitious roots that arise from the mistletoe stem and traverse the host bark, eventually establishing secondary haustorial connections with the host (Calvin and Wilson 2006). The haustorium is the point at which the mistletoe penetrates the host tree tissue. The presence of epicortical roots was supported by observations made during ecological studies.

\section{Severity of the mistletoe threat}

There is general consensus among researchers working in this location that the population of amla is declining. The decline has been attributed to excessive and destructive methods of harvesting and fire, with an additional role ascribed to mistletoe infection (Sinha 2000). In contrast, harvesters cite mistletoe infection as the main threat, quoting a population decline of approximately $50 \%$ in the last 10-20 years as a direct result of infection. They also 
Fig. 2. Host species for mistletoe (Taxillus tomentosus), identified by interviews and forest surveys. Harvesters cited an average of $8.5( \pm 2.7)$ species each. Grey bars indicate the proportion of harvesters $(n=47)$ citing each species. Black bars indicate the proportion of the total number of observed mistletoe infections $(\mathrm{n}=512)$ attributable to a particular host. Asterisks indicate hosts identified in forest surveys.

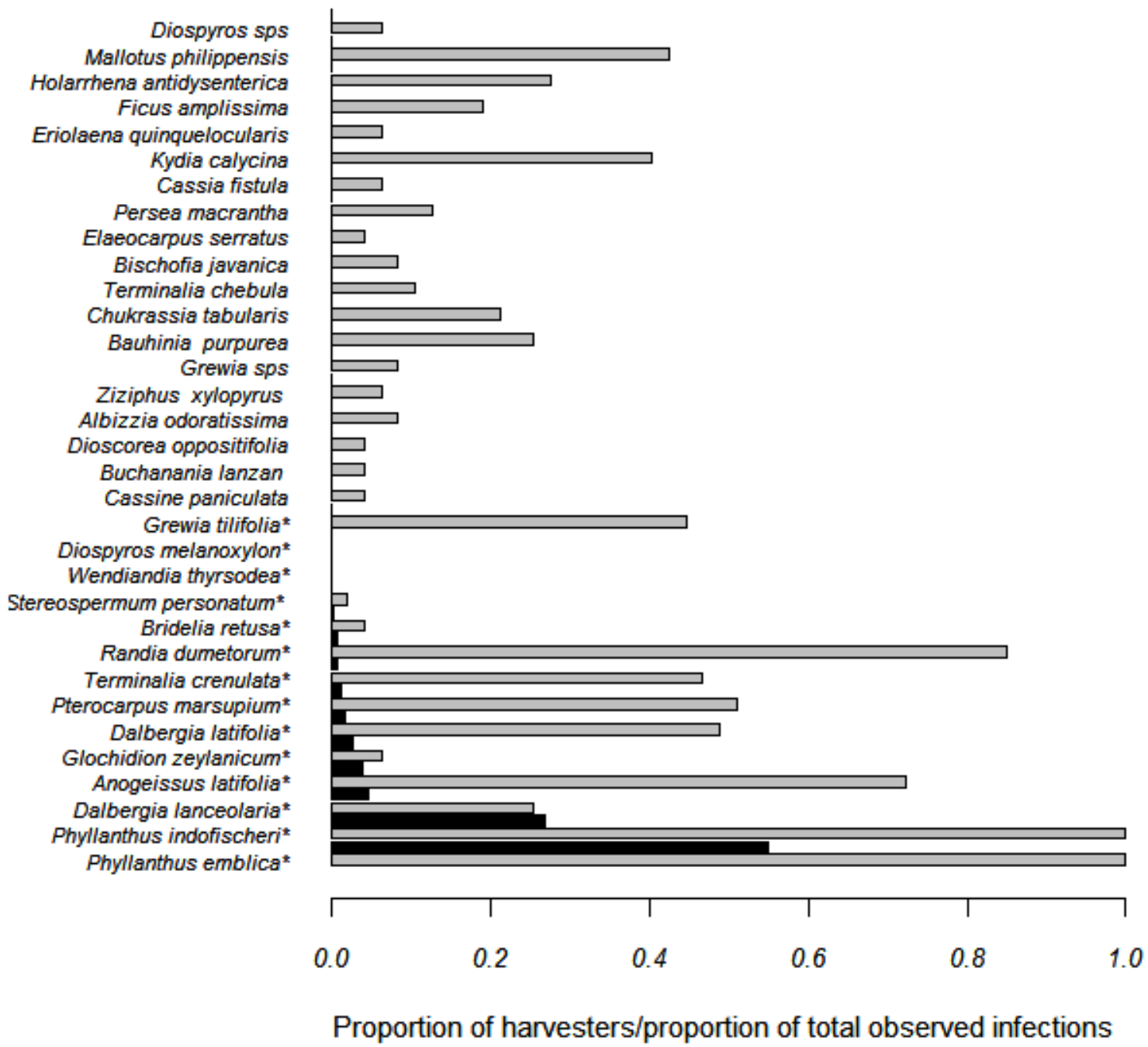

report a decline in the number of days spent harvesting and the amount harvested per day, as well as an increase in distance travelled for harvesting, an additional cost in terms of time foregone for other activities. They reported a mean decline of $88.5 \mathrm{~kg} /$ day and 15 days in the quantity and duration of harvesting, respectively, representing a substantial reduction in the total annual collection of approximately $80 \%$ on average per individual.
The Forest Department keeps annual records of the amla harvest. Over the 15-year period considered, these records highlighted significant temporal variability in fruit production, but do not appear to show evidence of a decline in yield (Fig. 3). In fact, these records have been used as evidence for sustainable harvesting. Price changes cited by harvesters over the same period matched those in official harvest records, providing evidence of 
reliable recall of historical harvest levels (SaenzArroyo et al. 2005).

\section{Managing mistletoe infection}

With no current formal response to the threat posed by mistletoe infection, we aimed to gather information regarding approaches that could be implemented in a formal management program. Suggestions from harvesters included controlled burning, branch chopping, and chemical control (Table 3). Just less than one-half of harvesters suggested that branch chopping was the most suitable response, but many also pointed out the practical limitations of this, specifically that the prevalence of infection means that significant time would be required to implement this for a large number of trees. Removal by hand was mentioned, but dismissed as not being a realistic option because of practical limitations, being physically difficult, ineffective in terms of regaining fruit production on branches from which mistletoes are removed, and impermanent. The mistletoe re-grows from tissue remaining with the host branch and from epicortical roots within $<1$ year. These explanations match the findings of an experimental assessment of this management technique (Rist et al. 2008b).

All harvesters gave the same account with regard to the effect of fire on both mistletoes and infected trees: fire kills mistletoes, but does not adversely affect amla trees. Harvesters were asked about current and past fire regimes. All said that the Forest Department had now banned fire, but prior to the ban, a ground-level fire occurred annually, spreading $15-30 \mathrm{~km}$ over a period of up to two weeks. Harvesters said that trees were not damaged and that when the rains arrived, re-growth of herbs and grasses was rapid. However, only $21 \%$ suggested that fire was the best approach for mistletoe management in the current situation. Many harvesters that advocated chopping also mentioned fire, but said that the high prevalence of the invasive shrub Lantana camara and its intense flammability prohibited burning as an approach to mistletoe control. In talking about the recent environmental history of the area, all harvesters claimed that 20 years ago, the forest was free from L. camara, at which time it was easy to see and move around in the forest and the microclimate was more favourable. They believe that $L$. camara has replaced the former grass understory and that it now prevents the growth of tree saplings. They maintain that forest fire is a natural part of the system, but that it is now more intense and sporadic, in some cases causing significant damage when not properly controlled. Fire is suspected to be responsible for the high mortality rates of amla seedlings identified in previous studies (Ganesan and Setty 2004), but interestingly, no harvesters mentioned the implications of fire for amla regeneration.

Two harvesters suggested chemical means of control, one saying that the government should spray herbicide because removal by hand or by chopping would be impossible because of the scale of infection. Additionally, one harvester suggested that the best approach would be to limit seed dispersal, and that by targeting the period when fruit are ripening, the mistletoe population could be effectively controlled. This is an interesting suggestion, given recent publications investigating such strategies in the context of invasive species (e. g., Gosper et al. 2005).

\section{DISCUSSION}

Our results illustrate the considerable body of traditional knowledge held by the indigenous inhabitants of the BRT and its potential for use in tackling a specific management issue. Previous studies have demonstrated the Soligas' considerable knowledge of their forest environment (Uma Shaanker et al. 2004), including the use of this knowledge in management (Lele et al. 1998, Shanker et al. 2005, Setty et al. 2008). Our investigation indicates that TEK can be useful as a source of quantitative information. It also demonstrates situations in which such information may be most useful, and additionally, in the context of this site, when it may be misleading or inaccurate.

\section{Comparing traditional ecological knowledge and data from ecological studies}

In general, data from ecological studies and TEK matched well. Harvesters provided accurate information on infection characteristics, including primary host species, mistletoe distribution across forest types and within the amla population, mistletoe phenology, and optimal growing conditions. TEK provided estimates of quantitative variables of management significance, e.g., prevalence of infection, in considerably less time and at less expense than scientific investigations. However, there were some discrepancies between 
Fig. 3. Total amla harvest between 1990 and 2005. Data for the Biligiri Rangaswamy Temple Wildlife Sanctuary for 1990-2005, provided by the Large-scale Adivasi Multipurpose Society of Chamarajanagar, Karnataka, India.

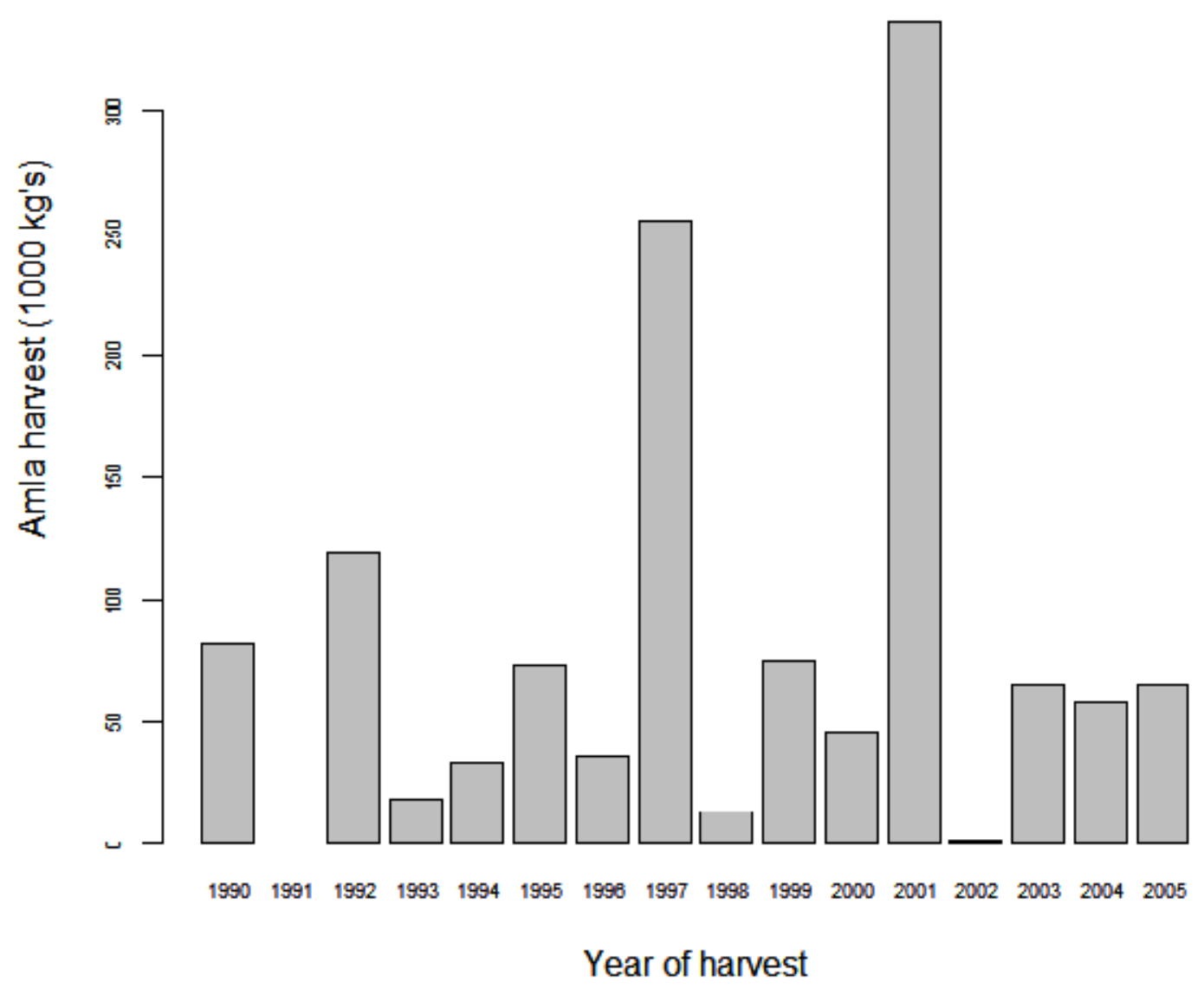

the two types of knowledge, most notably for secondary host species, dispersal mechanisms, and the differential effects of infection on P. emblica and P. indofischeri.

The fact that harvesters identified more than double the number of host species as found in forest surveys suggests that a survey of 60 forest plots was not extensive enough to detect some rarer mistletoehost associations, particularly for host species of low abundance. Misidentification by harvesters of mistletoe or host species seems unlikely. Previous studies have demonstrated the high concordance between local Soliga names and scientific species classifications for plants, birds, and animals
(Ganeshaiah and Uma Shaanker 1998). In fact, although the Soligas recognize Phyllanthus as two species based upon vegetative characters (Ganesan 2003), previous scientific studies did not distinguish between $P$. emblica and $P$. indofischeri (Murali et al. 1996, Shankar et al. 1998). More extensive sampling is required to conclusively establish the relative accuracy of TEK and field surveys in this respect, but our findings suggest that TEK may be particularly valuable as a source of information on rare events, i.e., rare host-mistletoe associations, that may require considerable fieldwork to identify. TEK may additionally be useful in the validation of field results. Indeed, a significant benefit of combining the use of TEK and conventional 
Table 3. Management responses advocated by amla harvesters. ${ }^{\dagger}$

\begin{tabular}{lc}
\hline \hline Management approach & Proportion of harvesters \\
\hline Branch chopping & $45 \%$ \\
Don't know & $30 \%$ \\
Fire & $21 \%$ \\
Chemical control & $4 \%$ \\
Removal by hand & $0 \%$ \\
\hline
\end{tabular}

$\dagger$ Although harvesters provided a clear statement on the management approach they viewed as preferable, many mentioned additional approaches. Therefore, the results are given as percentages of the summed total references to all approaches.

¥The Forest Department currently prohibits branch chopping and advocates removal by hand.

scientific data in management may be that the two sources of information might be used to check against the other, providing more robust conclusions upon which to base management.

The use of TEK extended current knowledge regarding mistletoe bird dispersers. Several mammals, including squirrels and rats, were identified by harvesters as fruit consumers, but dispersal of Taxillus tomentosus by anything other than birds has not previously been documented in the literature. However, Romiciops australis, an Argentinean marsupial, has been identified as the exclusive disperser of the seeds of the Loranthaceous mistletoe Tristerix corymbosus (Amico and Aizen 2000). Because of a lack of previous studies of the dispersal of this particular mistletoe, the possibility that mammals also play a role in the dispersal of this species cannot be discounted. However, the results also highlight the importance of framing questions carefully; when asked directly what they thought was responsible for spreading the mistletoes, the answers were less reliable, for example, the citing of wind by $20 \%$ of harvesters. Fruits of T. tomentosus, like those of other mistletoes, have an endozoochorous dispersal mechanism (Calder and Bernhardt 1983, Reid 1995); efficient dispersal requires not only the ingestion and transport of the sticky seeds produced by these plants, but also their active placement on the branches of an appropriate host. Although dispersal by mammals is feasible, wind dispersal is highly unlikely. The observational information from harvesters appears to be more accurate than that based on their understanding or interpretation of specific processes or mechanisms. This has not been the case in other systems, where harvesters have elucidated complex biological or ecological processes (e.g., Donovan and Puri 2004). We speculate that this may be the consequence of mistletoe infection being a relatively novel problem for resource users in BRT.

Opinion on the different susceptibilities of $P$. emblica and $P$. indofischeri was consistent among harvesters, but conflicted with evidence from scientific studies. Failure to account for different mean intensities of infection between P. emblica and $P$. indofischeri in previous scientific investigations of the effects on growth and productivity (Sinha and Bawa 2000, Setty 2004) may account for this discrepancy; trees with different levels of infection will certainly display variation in mortality rates. $P$. emblica was considered to be most severely affected, yet this species also tends to have a larger number of mistletoe infections. After controlling for the number of infections, it may be the case that $P$. indofischeri is affected to a greater degree, as harvesters indicated. 
In the case of the effects of infection on amla productivity, TEK and scientific data also differed significantly, yet an explanation for this is not apparent. It is often assumed that the results generated by a scientific study are more accurate, but we hesitate to make this judgment. As the host species example illustrates, scientific studies have their own inaccuracies. The scientific estimate for the effect of mistletoe infection on amla productivity came from one study carried out as part of a three- to four-year research project. In comparison, the TEK estimate was provided by 47 people who have observed the system for many years. Considering this, we should give careful consideration to our bias in assuming which information is more accurate.

\section{Traditional ecological knowledge in the assessment of sustainable harvesting}

To date, it has been claimed that the harvesting of amla in BRT is sustainable (Setty 2004). However, our results raise serious concerns about the viability of the amla resource. Combining harvester knowledge of current and historical collection patterns with official harvest records suggests that an increase in the number of individuals participating in the amla harvest may mask a declining resource base, with significant implications for harvester livelihoods. Monitoring based on quantitative biological variables alone is insufficient (Stem et al. 2005). In the absence of additional information on harvesting effort, harvested quantities cannot be taken as direct indicators of temporal trends in fruit availability. These findings emphasize the need to take account of other harvesting trends when assessing sustainability, for example, the number of participating harvesters and changes in harvester behavior such as the distance travelled by harvesters, number of trees harvested, and method of harvesting. Such issues have already been emphasized for fisheries management and bushmeat hunting (Walters and Martel 2004, Rist et al. 2008a). Such aspects of harvester behavior may provide important information on resource status and can be a useful gauge for monitoring the sustainable collection of NTFPs (Rist et al. 2008b).

The level of population decline suggested by harvesters is of significant concern. Recall could not be tested because of the lack of historical information against which to assess current tree densities. Although official price information supported harvester reports, price is not contested, but quantity is. The reliability of harvesting data involving recall periods of up to 12 months has been demonstrated to be good in other locations (Jones et al. 2008), and large numbers of dead infected trees provide confidence in harvester reporting.

Despite reports that $P$. emblica typically occurs at higher densities than $P$. indofischeri (Balachander 2002), forest surveys at BRT failed to reveal a difference between the two species (Rist et al. $2008 b$ ). Where infection is causing tree mortality, this could reflect the higher prevalence of infection in P. emblica (Rist et al. 2008b). The extent to which any changes in host density have occurred as a consequence of mistletoe-induced mortality, and additionally, the degree to which such changes could further influence the dynamics of amlamistletoe interactions, require further attention.

Commercialization of the amla resource occurred in the early 1980s. To what extent harvesting of this resource may have played a role in the reported decline in tree density is yet to be established. Preliminary modeling studies (Sinha and Bawa 2000) suggest that current harvesting levels do not affect population growth rates adversely, but information on past harvesting regimes would be necessary to eliminate the possibility that a previously more intensive harvesting regime played some role in the current population density and structure. More detailed modeling is needed that includes the effects on population dynamics of potentially interacting factors, which are likely to be synergistic.

\section{Management response}

TEK is a source of novel information that could be used for the formulation of a management response to mistletoe infection. Only the roles of intra- and inter-tree dispersal of mistletoe seed in the intensification of mistletoe infection on individual trees have been considered previously. Spread via epicortical roots may have significant implications for the selection and implementation of specific control measures, and in this case, provides further support for branch cutting as the most appropriate short-term management response (Rist et al. 2008b). Currently, this technique is prohibited by the Forest Department. Our results provide evidence to support a greater role for local communities in the current management of the BRT sanctuary. 
Institutions and communities often blame someone else for resource management problems, and this is particularly the case in this example. The local community considers that decline in the amla population has been caused by the Forest Department's policy of fire prevention; they consider that fire previously regulated mistletoe populations. The Forest Department claims that local people overharvest and harvest destructively. The scientific community has supported the Forest Department perspective indirectly, both through the nature of the research conducted and the discouragement of harvesting practices considered damaging without prior assessment of their relative merits (Rist et al. 2008b). Thus, it is all the more important to seek management approaches that integrate information from a variety of sources representing the full range of stakeholders.

\section{CONCLUSION}

Management at BRT faces two major challenges. First, despite evidence indicating the serious nature of the mistletoe threat to amla, current monitoring programs have not highlighted the scale of decline in the population. Second, disagreements over approaches to managing mistletoe infection remain unaddressed and unresolved. TEK has provided information relevant to both of these challenges. Our results highlight the need to focus less on issues of "correctness" with regard to the use of TEK and to place more emphasis on what it can add to resource management when used in combination with standard scientific approaches. The limitations and biases inherent in both TEK and scientific studies should be recognized within the particular management context in which they are used. Whereas scientific studies may offer precise measurement, they can be narrow in focus and expensive to implement. TEK-based methods may compromise on accuracy for specific variables, but may be inexpensive and incorporate larger temporal or spatial sample sizes. Trade-offs between information accuracy and precision on the one hand, and the resources available for assessment on the other, make rapid surveys of TEK a potentially valuable source of information. TEK studies can also help identify areas of concern for communities and resource users, making conservation and management more locally relevant. Indeed, the engagement of local people may be the most important reason for using TEK, particularly in areas where there is conflict over resource management.

There has been a call to move beyond the process of comparing TEK and information from scientific studies toward their greater integration in resource management (Brook and McLachlan 2005). In contrast to previous authors, we think that conservation and resource management will benefit from their continued comparison. TEK can fill information gaps and highlight promising directions for management and further research, but must be used in full recognition of its limitations. It can be expanded upon through scientific methods, whose limitations must also be recognized, in addition to local experimentation based on traditional management practices. Adaptively developing and testing our understanding with the participation of local people and resource users, and designing resource management solutions that are compatible with local ethics, may be more culturally appropriate and therefore more likely to be accepted and successful. Additionally, such methods may be a more time-efficient and cost-effective approach to resource management and conservation.

Responses to this article can be read online at:

http://www.ecologyandsociety.org/voll5/iss 1/art3/responses/

\section{Acknowledgments:}

We are grateful to the Karnataka Forest Department for permission to work in the BRT Sanctuary and to the Ashoka Trust for Research in Ecology and Environment (ATREE) for supporting our research. We thank the Solig a communities of BRT for sharing their time and knowledge, as well as H. M. Krishnan and the field assistants and drivers at the BRT field station for their help in the field. We are also grateful to three anonymous reviewers who shared their insights to improve this manuscript. This work was funded by an ESRC/NERC studentship to L. R. while at Imperial College, London. 


\section{LITERATURE CITED}

Acheson, J. M., J. A. Wilson, and R. S. Steneck. 1998. Managing chaotic fisheries. Pages 390-413 in F. Berkes, C. Folke, and J. Colding, editors. Linking social and ecological systems: management practices and social mechanisms for building resilience. Cambridge University Press, Cambridge, UK.

Ali, S., and S. D. Ripley. 1983. Handbook of the birds of India and Pakistan: together with those of Bangladesh, Nepal, Bhutan, and Sri Lanka. Oxford University Press, Delhi, India.

Amico, G., and M. A. Aizen. 2000. Mistletoe seed dispersal by a marsupial. Nature 408(6815):929-930.

Aukema, J. E., and C. Martínez del Rio. 2002. Where does a fruit-eating bird deposit mistletoe seeds? Seed deposition patterns and an experiment. Ecology 83(12):3489-3496.

Balachander, G. 2002. Amla (Phyllanthus emblica). Pages 240-245 in P. Shanley, A. R. Pierce, S. A. Laird, and S. A. Guillén, editors. Tapping the green market: certification and management of nontimber forest products. Earthscan, London, UK.

Berkes, F. 1999. Sacred ecology: traditional ecological knowledge and resource management. Taylor \& Francis, Philadelphia, Pennsylvania, USA.

Berkes, F., J. Colding, and C. Folke. 2000. Rediscovery of traditional ecological knowledge as adaptive management. Ecological Applications 10 (5):1251-1262.

Bowen-Jones, E., and A. Entwistle. 2002. Identifying appropriate flagship species: the importance of culture and local contexts. Oryx $\mathbf{3 6}$ (2):189-195.

Brook, R. K., and S. M. McLachlan. 2005. On using expert-based science to "test" local ecological knowledge. Ecology and Society 10(2): r3. [online] URL: http://www.ecologyandsociety.org/vol10/iss2/ resp3/.

Calder, M., and P. Bernhardt, editors. 1983. The biology of mistletoes. Academic Press, Sydney, Australia.
Calvin, C. L., and C. A. Wilson. 2006. Comparative morphology of epicortical roots in Old and New World Loranthaceae with reference to root types, origin, patterns of longitudinal extension and potential for clonal growth. Flora 201(1):51-64.

Castello, L., J. P., Viana, G. Watkins, M. PinedoVasquez, and V. A. Luzadis. 2009. Lessons from integrating fishers of Arapaima in small-scale fisheries management at the Mamirauá Reserve, Amazon. Environmental Management 43(2):197-209.

Colding, J. 1998. Analysis of hunting options by the use of general food taboos. Ecological Modelling 110(1):5-17.

Couzin, J. 2007. Opening doors to native knowledge. Science 315:1518-1519.

Danielsen, F., N. D. Burgess, and A. Balmford. 2005. Monitoring matters: examining the potential of locally based approaches. Biodiversity and Conservation 14(11):2507-2542.

Davidar, P. 1978. Dispersal in some Loranthaceae of the Nilgiris. Journal of the Bombay Natural History Society 75:943-945.

Davidar, P. 1983. Similarity between flowers and fruits in some flowerpecker pollinated mistletoes. Biotropica 15(1):32-37.

Davis, A., and J. R. Wagner. 2003. Who knows? On the importance of identifying "experts" when researching local ecological knowledge. Human Ecology 31(3):463-489.

Donovan, D. G., and R. K. Puri. 2004. Learning from traditional knowledge of non-timber forest products: Penan Benalui and the autecology of Aquilaria in Indonesian Borneo. Ecology and Society 9(3): 3. [online] URL: http://www.ecologya ndsociety.org/vo19/iss3/art3/.

Drew, J. A. 2005. Use of traditional ecological knowledge in marine conservation. Conservation Biology 19(4):1286-1293.

Fraser, D. J., T. Coon, M. R. Prince, R. Dion, and L. Bernatchez. 2006. Integrating traditional and evolutionary knowledge in biodiversity conservation: a population level case study. Ecology and Society 
11(2): 4. [online] URL: http://www.ecologyandsociety. org/vol11/iss $2 /$ art $4 /$.

Freeman, M. M. R. 1992. The nature and utility of traditional ecological knowledge. Northern Perspectives 20(1):9-12.

Gadgil, M., F. Berkes, and C. Folke. 1993. Indigenous knowledge for biodiversity conservation. Ambio 22(2-3):151-156.

Ganesan, R. 2003. Identification, distribution and conservation of Phyllanthus indofischeri, another source of Indian gooseberry. Current Science 84 (12):1515-1518.

Ganesan, R., and R. S. Setty. 2004. Regeneration of Amla, an important non-timber forest product from southern India. Conservation and Society 2 (2):365-375.

Ganeshaiah, K., and R. Uma Shaanker. 1998. BiligiriRanga Hills B R Hills, a geographic chip of the Western Ghats. Pages 4-6 in K. N. Ganeshaiah, R. Uma Shaanker, and K. S. Bawa, editors. Biligiri Rangaswamy Temple Wildlife Sanctuary: natural history, biodiversity and conservation. Ashoka Trust for Research in Ecology and the Environment and Vivekananda Girijana Kalyana Kendra, Bangalore, India.

Gilchrist, G., M. Mallory, and F. Merkel. 2005. Can local ecological knowledge contribute to wildlife management? Case studies of migratory birds. Ecology and Society 10(1): 20. [online] URL: http://www.ecologyandsociety.org/vol10/iss 1/art20/

Gosper, C. R., C. D. Stansbury, and G. VivianSmith. 2005. Seed dispersal of fleshy-fruited invasive plants by birds: contributing factors and management options. Diversity and Distributions 11(6):549-558.

Hanna, S. S. 1998. Managing for human and ecological context in the Maine soft shell clam fishery. Pages 190-210 in F. Berkes, C. Folke, and J. Colding, editors. Linking social and ecological systems: management practices and social mechanisms for building resilience. Cambridge University Press, Cambridge, UK.

Hegde, R., S. Suryaprakash, L. Achoth, and K. S. Bawa. 1996. Extraction of non-timber forest products in the forests of Biligiri Rangan Hills, India. 1. Contribution to rural income. Economic Botany 50(3):243-251.

Hobbs, N. T. 2003. Challenges and opportunities in integrating ecological knowledge across scales. Forest Ecology and Management 181(1-2):223-238.

Johannes, R. E. 1998. The case for data-less marine resource management: examples from tropical nearshore finfisheries. Trends in Ecology and Evolution 13(6):243-246.

Jones, J. P. G., M. M. Andriamarovololona, N. Hockley, J. M. Gibbons, and E. J. MilnerGulland. 2008. Testing the use of interviews as a tool for monitoring trends in the harvesting of wild species. Journal of Applied Ecology $\mathbf{4 5}$ (4):1205-1212.

Laird, S. A., editor. 2002. Biodiversity and traditional knowledge: equitable partnerships in practice. Earthscan, London, UK.

Lele, S., K. S. Murali, and K. S. Bawa. 1998. Community enterprise for conservation in India: Biligiri Rangaswamy Temple Sanctuary. Pages 449-466 in A. Kothari, N. Pathak, R. V. Anuradha, and B. Taneja, editors. Communities and conservation: natural resource management in South and Central Asia. Sage Publications, New Delhi, India.

Mallory, M. L., H. G. Gilchrist, A. J. Fontaine, and J. A. Akearok. 2003. Local ecological knowledge of Ivory Gull declines in Arctic Canada. Arctic 56(3):293-298.

Martin, G. J. 2004. Ethnobotany: a methods manual. Earthscan, London, UK.

Murali, K. S., U. Shankar, R. Uma Shaanker, K. N. Ganeshaiah, and K. S. Bawa. 1996. Extraction of non-timber forest products in the forests of Biligiri Rangan Hills, India. 2. Impact of NTFP extraction on regeneration, population structure, and species composition. Economic Botany 50 (3):252-269.

Norton, D. A., and N. Reid. 1997. Lessons in ecosystem management from management of threatened and pest loranthaceous mistletoes in New Zealand and Australia. Conservation Biology 11 (3):759-769. 
Pierotti, R., and D. Wildcat. 2000. Traditional ecological knowledge: the third alternative. Ecological Applications 10(5):1333-1340.

Reid, N. 1995. Mistletoe - impacts and management. Pages 40-47 in A. Kater, editor. Proceedings of the conference After Dieback: Redressing Agricultural Tree Decline in NSW. Greening Australia, Sydney, Australia.

Reid, N., and R. Lange. 1988. Host specificity, dispersion and persistence through drought of two arid zone mistletoes. Australian Journal of Botany 36(3):299-313.

Rist, J., J. M. Rowcliffe, G. C. Cowlishaw, and E. J. Milner-Gulland. 2008a. Evaluating measures of hunting effort in a bushmeat system. Biological Conservation 141(8):2086-2099.

Rist, L. 2009. Assessing a threat to sustainable NTFP harvest using ecological data and traditional ecological knowledge. Dissertation. Imperial College London, London, UK.

Rist, L., R. Uma Shaanker, E. J. Milner-Gulland, and J. Ghazoul. 2008b. Managing mistletoes: the value of local practices for a non-timber forest resource. Forest Ecology and Management 255 (5-6):1684-1691.

Saenz-Arroyo, A., C. M. Roberts, J. Torre, M. Carino-Olvera, and R. R. Enriquez-Andrade. 2005. Rapidly shifting environmental baselines among fishers of the Gulf of California. Proceedings of the Royal Society B: Biological Sciences 272:1957-1962.

Schwartzman, S., D. Nepstad, and A. Moreira. 2000. Arguing tropical forest conservation: people versus parks. Conservation Biology 14(5):1370-1374.

Setty, R. S. 2004. Ecology and productivity studies on some non-timber forest products of Biligiri Rangaswamy Temple Wildlife Sanctuary. Dissertation. University of Mysore, Mysore, India.

Setty, R. S., K. Bawa, T. Ticktin, and C. M. Gowda. 2008. Evaluation of a participatory resource monitoring system for nontimber forest products: the case of amla (Phyllanthus spp.) fruit harvest by Soligas in south India. Ecology and Society 13(2): 19. [online] URL: http://www.ecolog yandsociety.org/vol13/iss2/art19/.
Shankar, U., R. Hegde, and K. S. Bawa. 1998. Extraction of non-timber forest products in the forests of Biligiri Rangan Hills, India. 6. Fuelwood pressure and management options. Economic Botany 52(3):320-336.

Shanker, K., A. Hiremath, and K. Bawa. 2005. Linking biodiversity conservation and livelihoods in India. PLoS Biology 3(11): e394. [online] URL: http://www.plosbiology.org/article/info\%3Adoi\% 2F10.1371\%2Fjournal.pbio.0030394.

Sheil, D., and A. Lawrence. 2004. Tropical biologists, local people and conservation: new opportunities for collaboration. Trends in Ecology and Evolution 19(12):634-638.

Sheil, D., and S. Wunder. 2002. The value of tropical forest to local communities: complications, caveats, and cautions. Conservation Ecology 6(2): 9. [online] URL: http://www.consecol.org/vol6/iss2/ art9/.

Shrestha, T. K. 2000. Birds of Nepal: field ecology, natural history, and conservation: with reference to those of India, Bangladesh, Bhutan, Pakistan, and Sri Lanka: photographic field guide. Bimala Shrestha, Kathmandu, Nepal.

Sinha, A. 2000. Sustainability of fruit extractions from two non-timber forest product tree species, Phyllanthus emblica and P. indofischeri, in the forests of south India. Dissertation. University of Massachusetts, Boston, Massachusetts, USA.

Sinha, A., and K. S. Bawa. 2002. Harvesting techniques, hemiparasites and fruit production in two non-timber forest tree species in south India. Forest Ecology and Management 168(1-3):289-300.

Sinha, A., and S. Brault. 2005. Assessing sustainability of nontimber forest product extractions: how fire affects sustainability. Biodiversity and Conservation 14(14):3537-3563.

Stem, C., R. Margoluis, N. Salafsky, and M. Brown. 2005. Monitoring and evaluation in conservation: a review of trends and approaches. Conservation Biology 19(2):295-309.

Uma Shaanker, R., K. Ganeshaiah, B. Chinnappa Reddy, V. Krishnan, R. Rajagoplan, J. Aravind, A. Kumar, G. Vanraj, and D. Rao. 2002. Enhancing the role of forest fruits in 
sustaining livelihoods of forest margin communities. Technical report submitted to Department for International Development, London, UK.

Uma Shaanker, R., K. N. Ganeshaiah, S. Krishnan, R. Ramya, C. Meera, N. A. Aravind, A. Kumar, D. Rao, G. Vanaraj, J. Ramachandra, R. Gauthier, J. Ghazoul, N. Poole, and B. V. Chinnappa Reddy. 2004. Livelihood gains and ecological costs of non-timber forest product dependence: assessing the roles of dependence, ecological knowledge and market structure in three contrasting human and ecological settings in south India. Environmental Conservation 31(3):242-253.

Walters, C. J., and S. J. D. Martell. 2004. Fisheries ecology and management. Princeton University Press, Princeton, New Jersey, USA.

Wehi, P. M. 2009. Indigenous ancestral sayings contribute to modern conservation partnerships: examples using Phormium tenax. Ecological Applications 19(1):267-275. 
Appendix 1. Host species of mistletoe (Taxillus tomentosus), as identified by forest surveys and traditional ecological knowlegde from interviews. Species in bold were cited by $>40 \%$ of harvesters, but not detected in surveys. Species underlined were observed in surveys, but not cited by harvesters. Local names are given in parentheses.

\begin{tabular}{|c|c|c|c|c|c|}
\hline $\begin{array}{l}\text { Species (local } \\
\text { name) }\end{array}$ & Family & Number of stems & $\mathrm{TEK} \dagger$ & $\begin{array}{l}\text { Number of } \\
\text { observed infected } \\
\text { individuals }\end{array}$ & $\begin{array}{l}\text { Number of } \\
\text { expected infected } \\
\text { individuals } \ddagger\end{array}$ \\
\hline All species & & 4889 & - & 163 & - \\
\hline $\begin{array}{l}\text { Phyllanthus emblica } \\
\text { (Nai nelli) }\end{array}$ & Euphorbiaceae & 109 & Yes & 70 & 3.6 \\
\hline $\begin{array}{l}\text { Phyllanthus } \\
\text { indofischeri (Ittu } \\
\text { nelli) }\end{array}$ & Euphorbiaceae & 118 & Yes & 45 & 3.9 \\
\hline $\begin{array}{l}\text { Anogeissus latifolia } \\
\text { (Bejja) }\end{array}$ & Combretaceae & 1233 & Yes & 14 & 41.1 \\
\hline $\begin{array}{l}\text { Dalbergia } \\
\text { lanceolaria } \\
\text { (Buluga) }\end{array}$ & Fabaceae & 34 & Yes & 10 & 1.1 \\
\hline $\begin{array}{l}\text { Glochidion } \\
\text { zeylanicum (Anase) }\end{array}$ & Euphorbiaceae & 19 & Yes & 7 & 0.6 \\
\hline $\begin{array}{l}\text { Randia dumetorum } \\
\text { (Kare) }\end{array}$ & Rubiaceae & 723 & Yes & 3 & 24.1 \\
\hline $\begin{array}{l}\text { Grewia tilifolia } \\
\text { (Daddasalu) }\end{array}$ & Tiliaceae & 137 & Yes & 3 & 4.6 \\
\hline $\begin{array}{l}\text { Pterocarpus } \\
\text { marsupium (Honne) }\end{array}$ & Fabaceae & 148 & Yes & 3 & 4.9 \\
\hline $\begin{array}{l}\text { Terminalia } \\
\text { crenulata (Matti) }\end{array}$ & Combretaceae & 262 & Yes & 2 & 8.7 \\
\hline $\begin{array}{l}\text { Dalbergia latifolia } \\
\text { (Bite) }\end{array}$ & Fabaceae & 15 & Yes & 2 & 0.5 \\
\hline
\end{tabular}




\begin{tabular}{|c|c|c|c|c|c|}
\hline $\begin{array}{l}\text { Bridelia retusa } \\
\text { (Sironne) }\end{array}$ & Euphorbiaceae & 45 & Yes & 1 & 1.5 \\
\hline $\begin{array}{l}\text { Diospyros } \\
\text { melanoxylon } \\
\text { (Tubare) }\end{array}$ & Ebenaceae & 43 & Yes & 1 & 1.4 \\
\hline $\begin{array}{l}\text { Wendlandia } \\
\text { thyrsoidea (Koli) }\end{array}$ & Rubiaceae & $\underline{2}$ & $\underline{N o}$ & $\underline{1}$ & $\underline{0.1}$ \\
\hline$\frac{\frac{\text { Stereospermum }}{\text { personatum }}}{\text { (Padure) }}$ & $\underline{\text { Bignoniaceae }}$ & $\underline{38}$ & $\underline{N o}$ & $\underline{1}$ & $\underline{1.3}$ \\
\hline $\begin{array}{l}\text { Mallotus } \\
\text { philippensis } \\
\text { (Kesilu) }\end{array}$ & Euphorbiaceae & 9 & Yes & $\mathbf{0}$ & 0.3 \\
\hline $\begin{array}{l}\text { Kydia calycina } \\
\text { (Bende) }\end{array}$ & Malvaceae & 28 & Yes & $\mathbf{0}$ & 0.9 \\
\hline $\begin{array}{l}\text { Cassine paniculata } \\
\text { (Kaneeru) }\end{array}$ & Celastraceae & 57 & Yes & 0 & 1.9 \\
\hline $\begin{array}{l}\text { Buchanania lanzan } \\
\text { (Muruki) }\end{array}$ & Anacardiaceae & 19 & Yes & 0 & 0.6 \\
\hline $\begin{array}{l}\text { Dioscorea } \\
\text { oppositifolia } \\
\text { (Bellade) }\end{array}$ & Dioscoreaceae & 4 & Yes & 0 & 0.13 \\
\hline $\begin{array}{l}\text { Albizzia } \\
\text { odoratissima (Sele) }\end{array}$ & Fabaceae & 4 & Yes & 0 & 0.1 \\
\hline $\begin{array}{l}\text { Ziziphus xylopyrus } \\
\text { (Gotti) }\end{array}$ & Rhamnaceae & 1 & Yes & 0 & 0.03 \\
\hline Grewia sp. (Udupe) & Tiliaceae & 0 & Yes & 0 & 0 \\
\hline $\begin{array}{l}\text { Bauhinia purpurea } \\
\text { (Kanchuvala) }\end{array}$ & Caesalpinaceae & 35 & Yes & 0 & 1.7 \\
\hline $\begin{array}{l}\text { Chukrassia } \\
\text { tabularis (Kilanji) }\end{array}$ & Meliaceae & 0 & Yes & 0 & 0 \\
\hline
\end{tabular}




\begin{tabular}{|c|c|c|c|c|c|}
\hline $\begin{array}{l}\text { Terminalia chebula } \\
\text { (Arale) }\end{array}$ & Combretaceae & 57 & Yes & 0 & 1.9 \\
\hline $\begin{array}{l}\text { Bischofia javanica } \\
\text { (Neelalu) }\end{array}$ & Euphorbiaceae & 0 & Yes & 0 & 0 \\
\hline $\begin{array}{l}\text { Elaeocarpus } \\
\text { serratus (Kakkilu) }\end{array}$ & Elaeocarpaceae & 5 & Yes & 0 & 0.2 \\
\hline $\begin{array}{l}\text { Persea macrantha } \\
\text { (Karavadi) }\end{array}$ & Lauraceae & 35 & Yes & 0 & 1.7 \\
\hline $\begin{array}{l}\text { Chloroxylon } \\
\text { swietenia (Urigilu) }\end{array}$ & Rutaceae & 139 & Yes & 0 & 4.6 \\
\hline $\begin{array}{l}\text { Diospyros sp. } \\
\text { (Hasari) }\end{array}$ & Ebenaceae & 52 & Yes & 0 & 1.7 \\
\hline $\begin{array}{l}\text { Holarrhena } \\
\text { antidysenterica } \\
\text { (Ala) }\end{array}$ & Apocynaceae & 25 & Yes & 0 & 0.8 \\
\hline $\begin{array}{l}\text { Ficus amplissima } \\
\text { (Itchi) }\end{array}$ & Boraceae & 0 & Yes & 0 & 0 \\
\hline $\begin{array}{l}\text { Eriolaena } \\
\text { quinquelocularis } \\
\text { (Kathale) }\end{array}$ & Sterculiaceae & 8 & Yes & 0 & 0.3 \\
\hline $\begin{array}{l}\text { Cassia fistula } \\
\text { (Kakke) }\end{array}$ & Caesalpinaceae & 38 & Yes & 0 & 1.3 \\
\hline
\end{tabular}

